\title{
Blood Cholinesterases from Washington State Orchard Workers
}

Barry W. Wilson · John D. Henderson •

John L. Furman · Bruce E. Zeller •

David Michaelsen

Published online: 9 June 2009

(C) Springer Science+Business Media, LLC 2009

Erratum to: Bull Environ Contam Toxicol

DOI 10.1007/s00128-009-9724-6

The name of one of the authors was spelled incorrectly.

The correct spelling is David Michaelsen.

The online version of the original article can be found under doi:10.1007/s00128-009-9724-6.

B. W. Wilson $(\bowtie) \cdot$ J. D. Henderson

Department of Animal Science and Department Environmental Toxicology, University of California, Davis, CA 95616, USA

e-mail: bwwilson@ucdavis.edu

J. L. Furman · B. E. Zeller

Washington State Department of Labor \& Industries,

Olympia, WA 98504, USA

D. Michaelsen

Pathology Associates Medical Laboratory, Spokane,

WA 99204, USA 